\title{
Remediation of Polluted Water Using Natural Zeolitic Aluminosilicates/Lateritic Clay Ceramic Matrix Membrane
}

\author{
E. Ajenifuja, ${ }^{1}$ O. O. Akinwunmi, ${ }^{2}$ M. K. Bakare, ${ }^{3}$ J. A. Ajao, ${ }^{1}$ I. F. Adeniyi, ${ }^{4}$ and E. O. B. Ajayii ${ }^{2}$ \\ ${ }^{1}$ Materials and Electronics Division, Centre for Energy Research and Development, \\ Obafemi Awolowo University, Ile-Ife 220005, Nigeria \\ ${ }^{2}$ Department of Physics, Obafemi Awolowo University, Ile-Ife 220005, Nigeria \\ ${ }^{3}$ Department of Microbiology, Obafemi Awolowo University, Ile-Ife 220005, Nigeria \\ ${ }^{4}$ Department of Zoology, Obafemi Awolowo University, Ile-Ife 220005, Nigeria
}

Correspondence should be addressed to E. Ajenifuja, eajenifuja@cerd.gov.ng

Received 22 December 2011; Accepted 11 January 2012

Academic Editors: Y.-C. Liou and S. Marinel

Copyright (C) 2012 E. Ajenifuja et al. This is an open access article distributed under the Creative Commons Attribution License, which permits unrestricted use, distribution, and reproduction in any medium, provided the original work is properly cited.

\begin{abstract}
Microporous ceramic matrix membranes were prepared with complementary proportions of locally available zeolitic aluminosilicate materials and other abundant lateritic clay minerals. The membranes cast as circular disks $(22.78 \mathrm{~mm}$ diameter and $2.11 \mathrm{~mm}$ thickness) were treated with silver nitrate solution to discourage microbial growth on their surface and then sintered at $900 \pm 5^{\circ} \mathrm{C}$ for about 20 hours. Antimicrobial microfiltration process showed $87.24 \%$ to $100 \%$ bacterial rejection depending on the material combination ratio. Elemental characterization of the membrane materials was done using ion beam analysis (IBA) technique of particle induced X-ray emission (PIXE), while the physicochemical behaviour of the ceramic membranes was carried out through the analysis of the filtered water samples using atomic absorption spectroscopy (AAS), total dissolved solids (TDS), microbial, and $\mathrm{pH}$ analyses. Compositional characterization of raw materials showed comparatively low contents of impurities, such as $\mathrm{Fe}$ and $\mathrm{Ca}$, in the raw materials, but with high $\mathrm{SiO}_{2} / \mathrm{Al}_{2} \mathrm{O}_{3}$ ratios for the raw material which is important for zeolitic material synthesis. Regularly porous microstructure of mean pore diameter of between $50 \mathrm{~nm}$ and $100 \mathrm{~nm}$ was observed from the analyzed images obtained from ZEISS Supra 40 scanning electron microscope.
\end{abstract}

\section{Introduction}

Oxide, aluminosilicate, and silicate materials hold much promise for the preparation of porous ceramic composites. Aluminosilicate ceramic materials occupy an important place in this series, because they exhibit corrosive and abrasive stabilities, mechanical strength, heat resistance, and chemical durability [1]. Ceramic membranes have a wide range of domestic, industrial, and scientific uses, the most common of which is used in separation processes. Organic membranes are often currently used in industry and scientific establishments for separation and purification processes, but ceramic membranes offer several advantages over organic membranes. Ceramic membranes are more resistant than organic membranes to organic solvents, chlorine, and extremes of $\mathrm{pH}$. Ceramic membranes are also inherently more stable at high temperatures, thus allowing more efficient sterilization of process equipment than is possible with organic membranes. Ceramic membranes are generally quite resistant to microbial and biological degradation, which can occasionally be a problem with organic membranes. Ceramic membranes are also more mechanically stable under high pressures. The production of microporous aluminosilicate ceramic materials is of considerable practical interest, because they make it possible to design heat-insulating materials, membranes for filtration of liquids and gases, and catalyst supports [2] for hightemperature and chemical processes [1]. The asymmetric multilayer structure has often been used for preparation of ceramic membranes [3]. Membranes with asymmetric multilayer structure have the following shortages: first, their cost is high due to the multilayerforming and sintering process, and secondly, defects occur easily between layers because of the ceramic particle size changing suddenly and 
easy peel off from last support layer [3]. Those shortages especially the cost, limit their applications. Industry and research departments are searching new ceramic membrane which can be manufactured in one-step fabrication process. Adsorption is another popular technique for the removal of toxic elements from contaminated water [4] and the materials exhibiting this kind of separation characteristics are being considered as alternatives to traditional methods such as flocculation, coagulation, and ion exchange. It is a mass transfer operation in which contaminants present in a liquid phase are accumulated on a solid phase, thereby being removed from the liquid. Many research studies [47] have been done recently to explore the potential of using various alternative adsorbents. Adsorbents that stand out for high adsorption capacities are chitosan, zeolites waste slurry, clay, fly ash, coal, natural oxide, and activated carbon [8]. Also, studies by Wood and Mac-Atamney [9] showed that percolating columns of laterite, which is a good source of clay minerals, removed enough cadmium, chromium, and lead to undetectable concentrations. Natural clay mineral, zeolites and their combination were used in this work to prepare ceramic membranes for ultrafiltration and adsorption processes. Most investigations that were carried out by researchers $[3,10-15]$ on preparation and characterization of porous ceramic or aluminosilicate membranes were done through the use of commercialized ceramic products from manufacturers such as ceramic powder or membranes.

Moreover, synthetic zeolites [16, 17] prepared from chemical sources of silica and alumina are expensive and therefore, their use in environmental remediation is restricted due to high cost. These challenges of chemical cost and availability can be overcome by seeking cheaper natural raw materials with appropriate $\mathrm{SiO}_{2} / \mathrm{Al}_{2} \mathrm{O}_{3}$ ratio coupled with simple preparatory techniques for zeolite synthesis. In this work, locally available geological materials with suitable $\mathrm{SiO}_{2} / \mathrm{Al}_{2} \mathrm{O}_{3}$ ratio, such as aluminosilicates and lateritic clays, were formulated as precursors for membrane preparation using a simple chemical-mechanical process. The formulated materials were carefully compacted and then formed into porous composite ceramic membrane. The water purification behavior of the porous membranes test modules was investigated. It is believed that, using the readily available natural materials and a simple technique of manufacturing of the purification membranes, cost of production will be low and membrane purifier will be affordable. Compared to other starting materials, natural raw materials, such as clay minerals, natural zeolites, volcanic glasses, diatomite and other abundant silicate minerals, having natural porous microstructure and adsorption capacities offer an opportunity to provide low-cost, low-technology, efficient filtration system for rural areas with dispersed point sources of pollution.

\section{Materials and Methods}

2.1. Raw Materials. The zeolitic aluminosilicate materials used in this work was white fluffy clay which has been formed typically by intense weathering which has leached the source rocks leaving predominantly relatively pure white aluminosilicate raw material. Samples of the aluminosilicate materials were obtained from a quarry site near Jalingo, Taraba State, Nigeria. The laterite from which the clay mineral used was prepared was obtained from a construction site in Obafemi Awolowo University campus, Ile-Ife, Nigeria. The clay material being sourced from laterite was richer in iron oxide than the zeolitic raw material, also confirmed by PIXE analysis.

2.2. Sample Preparation for PIXE Analysis. The zeolitic aluminosilicate and clay samples were first air dried, and then the samples were ground into fine powder, and then pelletized using a hydraulic press machine with $25.4 \mathrm{~mm}$ stainless steel die. The raw material pellets were then loaded into the manually operated sample holder at the end-station of accelerator. The IAEA Soil-7 certified reference material was analyzed under the same experimental conditions, and the measured elemental concentrations were compared with the certified values and used as analytical quality control to validate the procedure. The other detail of routine experimental setup for routine PIXE analysis in this laboratory has been reported [18].

2.3. Membrane Precursor Preparation. Clay materials were separated from the rock matrix and other materials by carefully crushing the portion of interest of the matrix. A suspension was prepared by adding the separated clay mineral particles to distilled water in a $500 \mathrm{~mL}$ beaker. The clay material totally immersed and soaked in the distilled water was left for about 2 hours to aid dispersion of the clay particles in the water and sol formation. Afterwards, the mixture was stirred vigorously for about 20 minutes and left standing for about 5 minutes to maintain the fine clay particles in suspension. While the finer and lighter clay particles were still in suspension, the top coloured sol containing the clay suspensions was poured into a separate beaker. The process was repeated several times until a very fine clay mineral separate suspension was achieved. The clay suspension was now dialyzed using laboratory-grade filter paper and pure fine clay mineral particles collected as paste on the filter paper. The clay was oven-dried for 18 hours at $80^{\circ} \mathrm{C}$, thereby forming a solid clay powder, devoid of sands and other larger materials.

The zeolitic material used for this work was obtained as stated above; it was in solid form, white in colour but has a very light weight. Compare to the pure clay material, it contained lesser "impurities" such as sand and organic matters. The material was ground carefully in a mortal and the powder mixed with distilled water to form a colloid. It was stirred vigorously to obtain a complete mixture with the distilled water. The solution was left for 5 minutes for heavier particles and other foreign matter to settle at the base of the beaker, thereupon the suspension was poured into another beaker, and the process was repeated several times till a clear aluminosilicate suspension was obtained. The aluminosilicate suspension was then filtered using a laboratory grade filter paper, forming a white gel on the filter 
TAble 1: Aluminosilicate/clay formulations for ceramic membranes.

\begin{tabular}{lccc}
\hline \multirow{2}{*}{ Ceramic membrane } & \multicolumn{3}{c}{ Composition (w/w \%) } \\
& Pure clay & Zeolitic material & Additive \\
\hline CMF1 & 90 & - & 10 \\
CMF2A & 60 & 30 & 10 \\
CMF2B & 30 & 60 & 10 \\
CMF3 & - & 100 & - \\
\hline
\end{tabular}

paper. The collected aluminosilicate gel was then oven-dried for 18 hours at $80^{\circ} \mathrm{C}$; it formed a solid light-weight powder.

2.4. Ceramic Membrane Casting and Surface Antimicrobial Treatment. Ceramic membrane discs with different aluminosilicate/clay ratio formulations and lignocellulosic powder as pore-forming additives, which were composed essentially of cellulose, hemicelluloses, lignin, and other extractives, for the pure clay and clay/aluminosilicate matrices only were prepared. Table 1 shows the percentage composition (w/w) of each of the materials in the ceramic membrane matrix samples formed. Zeolitic material, laterite clay, and the poreforming additive combinations were vigorously mixed for about 30 minutes to enhance homogeneity; the mixed blends were packed into stainless steel die of $24.5 \mathrm{~mm}$ diameter and then carefully compacted with a load of $6803.89 \mathrm{~kg}$. The average thickness of each pressed test sample was $2.49 \mathrm{~mm}$ before sintering. The samples were initially heat-treated up to $400^{\circ} \mathrm{C}$ for 6 hours to drive off chemically bonded water, carbon, and other organic material that may be present in the matrix before surface biofilm growth inhibition treatment.

For the surface biofilm growth inhibition, a judicious amount of silver nitrate $\left(\mathrm{AgNO}_{3}\right)$ solution $(0.8 \mathrm{~g} /$ liter $)$ was prepared and used for the treatment of the disc ceramic membrane samples. The discs were immersed in the silver nitrate solution; the ceramic discs were impregnated with silver nitrate solution, with gradual capillarity adsorption. This was intended solely to limit growth of microbes on the membrane filter surface, thus it will have no effect on the bulk water pathogen reduction. After about 60 hours in static condition in the chemical medium, the microporous ceramic samples were removed from silver nitrate solution, then soaked briefly and rinsed with deionized water to remove any excess from the surface. Therefore, the ceramic discs were heat-treated in a furnace at temperature ranging from $100^{\circ} \mathrm{C}$ to $120^{\circ} \mathrm{C}$ in an air atmosphere to eliminate the water molecules present in the impregnated solution. Finally, the samples were sintered at $900^{\circ} \mathrm{C}$ for about 20 hours. At this temperature, the material was no longer truly clay, but had become a ceramic material with the required porous microstructure.

2.5. Water Sample Microfiltration Procedure. Membrane test modules were constructed using the ceramic discs with PVC pipe and other fittings. Water purification performance test were carried out on the samples using the water collected from River Opa; the dammed part of this river with treatment plant serving the university is located in Obafemi
Awolowo University campus, Ile-Ife, Nigeria. The water for the experiment was collected directly from the flowing portion of the river. For the filtration experiment, four ceramic membrane test modules were assembled with PVC pipes and fittings screwed to another four columns of PVC pipe arranged vertically. Each PVC pipes with appropriate fittings was $2 \mathrm{~m}$ long and $2 \mathrm{~cm}$ in diameter filled with source water, thus the geometry was to allow the water to move through the microporous ceramic membrane discs located at the base of the pipes under gravity. The feed water was supplied constantly into the pipes to maintain the hydrostatic pressure at height $2 \mathrm{~m}$ on the microporous ceramic membranes at the base of the pipe. The filtrates were collected separately from each of the tightly fitted test modules into $500 \mathrm{~mL}$ plastic kegs. The filtrates collected from each of the ceramic test modules were used for atomic absorption spectrometry (AAS) analysis for the determination of change in hardness of the water sample and heavy metal concentrations in the filtrates against the source water. Other qualitative and quantitative analyses, such as $\mathrm{pH}$, total dissolved solids (TDS), and microbial analysis were carried out on the filtrates and feed water.

2.6. Characterization Methods. Elemental and oxide composition analyses of the raw materials were carried out at the Centre for Energy Research and Development (CERD) ion beam analysis (IBA) facility at Obafemi Awolowo University, Ile-Ife, Nigeria. The facility has a NEC 5SDH $1.7 \mathrm{MeV}$ pelletron tandem accelerator, equipped withan RF charge exchange ion source. to provide proton and helium ions. The particular technique used was PIXE, and elemental and oxide concentrations were obtained concurrently using the spectrum analysis software, GUPIXWIN.

The following analytical techniques have been employed to characterize the ceramic membrane and the water samples collected from the filtration experiments: scanning electron microscopy (SEM) of the prepared membranes was carried out using ZEISS Supra 40 microscope (with GEMINI column) at ICTP, Italy, and optical images were obtained with NIKON ECLIPSE ME600L metallurgical/materials science microscope coupled with video camera AP2000MTI. The optical microscope images were analyzed for $3 \mathrm{D}$ surface morphology and pore size estimation using Image J image analysis software. The differential thermal analysis (DTA) of the aluminosilicate material was done using DTA 404 PC while the efficacy of the prepared microporous ceramic filter was assessed using the following analytical techniques: atomic absorption spectroscopy (AAS), total bacterial count, $\mathrm{pH}$, and total dissolved solids (TDS).

\section{Results and Discussion}

3.1. PIXE Analysis. GUPIXWIN spectral analytical software was used to analyze the data obtained from the PIXE technique. PIXE is a very good technique for nondestructive trace element analysis, and it gave interesting information on the elemental and chemical composition of the material. Therefore, the use of this particular analytical technique gave the opportunity of knowing the extent of impurities 
TABLE 2: Elemental concentrations of the raw materials determined by PIXE technique.

\begin{tabular}{lcccc}
\hline Element & \multicolumn{2}{c}{ Concentration $(\mathrm{ppm})$} & \multicolumn{2}{c}{ Statistical error $(\%)$} \\
\hline $\mathrm{Na}$ & Clay material & Zeolitic aluminosilicate & Clay material & 27.43 \\
$\mathrm{Mg}$ & 29187.0 & 37206.0 & 9.48 & 8.91 \\
$\mathrm{Al}$ & 3648.4 & 5524.9 & 0.79 & 3.31 \\
$\mathrm{Si}$ & 244295.9 & 81148.7 & 0.61 & 0.60 \\
$\mathrm{~K}$ & 213689.8 & 355515.2 & 1.11 & 2.49 \\
$\mathrm{Ca}$ & 8055.5 & 3018.3 & 5.45 & 1.51 \\
$\mathrm{Ti}$ & 1149.5 & 5451.1 & 0.82 & 1.85 \\
$\mathrm{~V}$ & 3229.3 & 836.3 & 7.01 & 7.44 \\
$\mathrm{Mn}$ & 190.4 & 135.5 & 2.48 & 28.72 \\
$\mathrm{Fe}$ & 311.9 & 18.1 & 0.56 & 0.65 \\
$\mathrm{Co}$ & 11668.9 & - & 4.12 & - \\
$\mathrm{Ni}$ & 1324.7 & - & 26.72 & - \\
$\mathrm{Cu}$ & 79.5 & - & 7.12 & - \\
$\mathrm{Zn}$ & 155.3 & 47.2 & 11.40 & - \\
$\mathrm{Sr}$ & 56.4 & - & 28.82 & - \\
\hline
\end{tabular}

(trace elements) present in the raw materials. In addition, the $\mathrm{SiO}_{2} / \mathrm{Al}_{2} \mathrm{O}_{3}$ ratio obtained from PIXE analysis can be used to predict whether the material could successfully be used in the treatment of contaminated water.

The result of the analysis for clay material is presented in Table 2, which showed that aluminium and silicon have the highest concentrations of $244295.9 \mathrm{ppm}$ and $213689.8 \mathrm{ppm}$, respectively. The other elements detected with comparative high concentrations are sodium and iron with $29187 \mathrm{ppm}$ and $11668.9 \mathrm{ppm}$. It was observed that iron concentration result has the lowest error margin of all the elements for the clay material. The rusty red colour of the clay material showed the presence of iron oxide in the matrix, even though the concentration of iron oxide in the clay material is much lower compare to the $\mathrm{Al}_{2} \mathrm{O}_{3}$ and $\mathrm{SiO}_{2}$ which accounted for $46.16 \mathrm{wt} \%$ and $45.71 \mathrm{wt} \%$ of the raw clay materials as presented in Table 3. Other elements detected in the clay material are $\mathrm{Mg}, \mathrm{K}, \mathrm{Ca}, \mathrm{Ti}, \mathrm{V}, \mathrm{Mn}, \mathrm{Co}, \mathrm{Ni}, \mathrm{Cu}, \mathrm{Zn}$, and $\mathrm{Sr}$ with their concentrations as shown in Table 2. Laterites are known to be very rich in iron, aluminium, silicon, and other elements detected in the representative sample analyzed. It is important to note that highly toxic and nonessential elements such as lead $(\mathrm{Pb})$ and mercury $(\mathrm{Hg})$ are absent in the clay as they were not detected in the matrix. The lateritic clay showed low $\mathrm{SiO}_{2} / \mathrm{Al}_{2} \mathrm{O}_{3}$ ratio (0.99), and this was appropriate for the formulation of low-Si zeolitic materials with high cation exchange capacity because of presence of more replacement of $\mathrm{Si}^{4+}$ by $\mathrm{Al}^{3+}$.

The analytical result of the aluminosilicate membrane material in Table 2 showed that silicon has the highest concentration of $355515.2 \mathrm{ppm}$ followed by aluminium with concentration of $81148.7 \mathrm{ppm}$. Nine other elements were detected in the zeolitic aluminosilicate samples, namely, $\mathrm{Na}$, $\mathrm{Mg}, \mathrm{K}, \mathrm{Ca}, \mathrm{Ti}, \mathrm{V}, \mathrm{Mn}, \mathrm{Fe}$, and Zn. Besides aluminium and silicon, other elements with remarkable concentrations are sodium (37206.0 ppm $\pm 27 \%$ ), magnesium (5524.9 ppm $\pm 8.91 \%)$, potassium (3018.3 ppm $\pm 2.49 \%)$, calcium
TABle 3: Chemical compositions of the ceramic membrane raw materials determined by PIXE analysis.

\begin{tabular}{|c|c|c|}
\hline Compound & $\begin{array}{c}\text { Clay raw } \\
\text { material (wt \%) }\end{array}$ & $\begin{array}{c}\text { Zeolitic raw } \\
\text { material (wt \%) }\end{array}$ \\
\hline $\mathrm{Na}_{2} \mathrm{O}$ & 3.93 & 5.02 \\
\hline $\mathrm{MgO}$ & 0.61 & 0.92 \\
\hline $\mathrm{Al}_{2} \mathrm{O}_{3}$ & 46.16 & 15.33 \\
\hline $\mathrm{SiO}_{2}$ & 45.72 & 76.06 \\
\hline $\mathrm{K}_{2} \mathrm{O}$ & 0.97 & 0.36 \\
\hline $\mathrm{CaO}$ & 0.16 & 0.76 \\
\hline $\mathrm{TiO}_{2}$ & 0.54 & 0.14 \\
\hline $\mathrm{V}_{2} \mathrm{O}_{3}$ & 0.03 & 0.02 \\
\hline $\mathrm{MnO}$ & 0.04 & 0.002 \\
\hline $\mathrm{FeO}$ & 1.50 & 0.45 \\
\hline $\mathrm{CoO}$ & 0.17 & - \\
\hline $\mathrm{NiO}$ & 0.01 & - \\
\hline $\mathrm{Cu}_{2} \mathrm{O}$ & 0.02 & - \\
\hline $\mathrm{ZnO}$ & 0.007 & 0.006 \\
\hline $\mathrm{SrO}$ & 0.006 & - \\
\hline $\begin{array}{l}\mathrm{SiO}_{2} / \mathrm{Al}_{2} \mathrm{O}_{3} \\
\text { ratio }\end{array}$ & 0.99 & 4.96 \\
\hline
\end{tabular}

$(5451.1 \mathrm{ppm} \pm 1.51 \%)$, and iron (3528.9 ppm $\pm 0.65 \%)$. From the result, it shown that the concentration of iron in the zeolitic aluminosilicate is far more less than what was determined for the clay material which had iron concentration of $11668.9 \mathrm{ppm} \pm 0.56 \%$. Expectedly, the iron oxide concentration was $1.5 \mathrm{wt} \%$ in the clay and $0.45 \mathrm{wt} \%$ in the aluminosilicates as shown in Table 3, and this could be inferred from their colours. Toxic elements such as mercury, lead, and some other heavy metals, which are harmful even at trace level, were not detected in the raw materials; this finding is encouraging, because problem 
TABLE 4: Atomic absorption spectroscopy result of water samples.

\begin{tabular}{|c|c|c|c|c|c|}
\hline \multirow{2}{*}{ Element } & \multicolumn{5}{|c|}{ Concentrations in water samples (ppm) } \\
\hline & WS1 & WS2A & WS2B & WS3 & WS4 \\
\hline $\mathrm{Mg}(2+)$ & 1.891 & 2.385 & 2.370 & 1.533 & 2.406 \\
\hline $\mathrm{Ca}(2+)$ & 2.657 & 3.008 & 2.908 & 1.419 & 3.311 \\
\hline $\mathrm{Mn}$ & Nil & Nil & Nil & Nil & 0.001 \\
\hline $\mathrm{Zn}(2+)$ & 0.073 & 0.128 & 0.121 & 0.147 & 0.183 \\
\hline $\mathrm{Fe}$ & Nil & Nil & Nil & 0.065 & 0.019 \\
\hline Co & Nil & Nil & Nil & Nil & Nil \\
\hline $\mathrm{K}(1+)$ & 5.997 & 5.956 & 5.824 & 6.210 & 4.550 \\
\hline $\mathrm{Na}(1+)$ & 2.358 & 2.324 & 2.293 & 2.446 & 2.133 \\
\hline
\end{tabular}

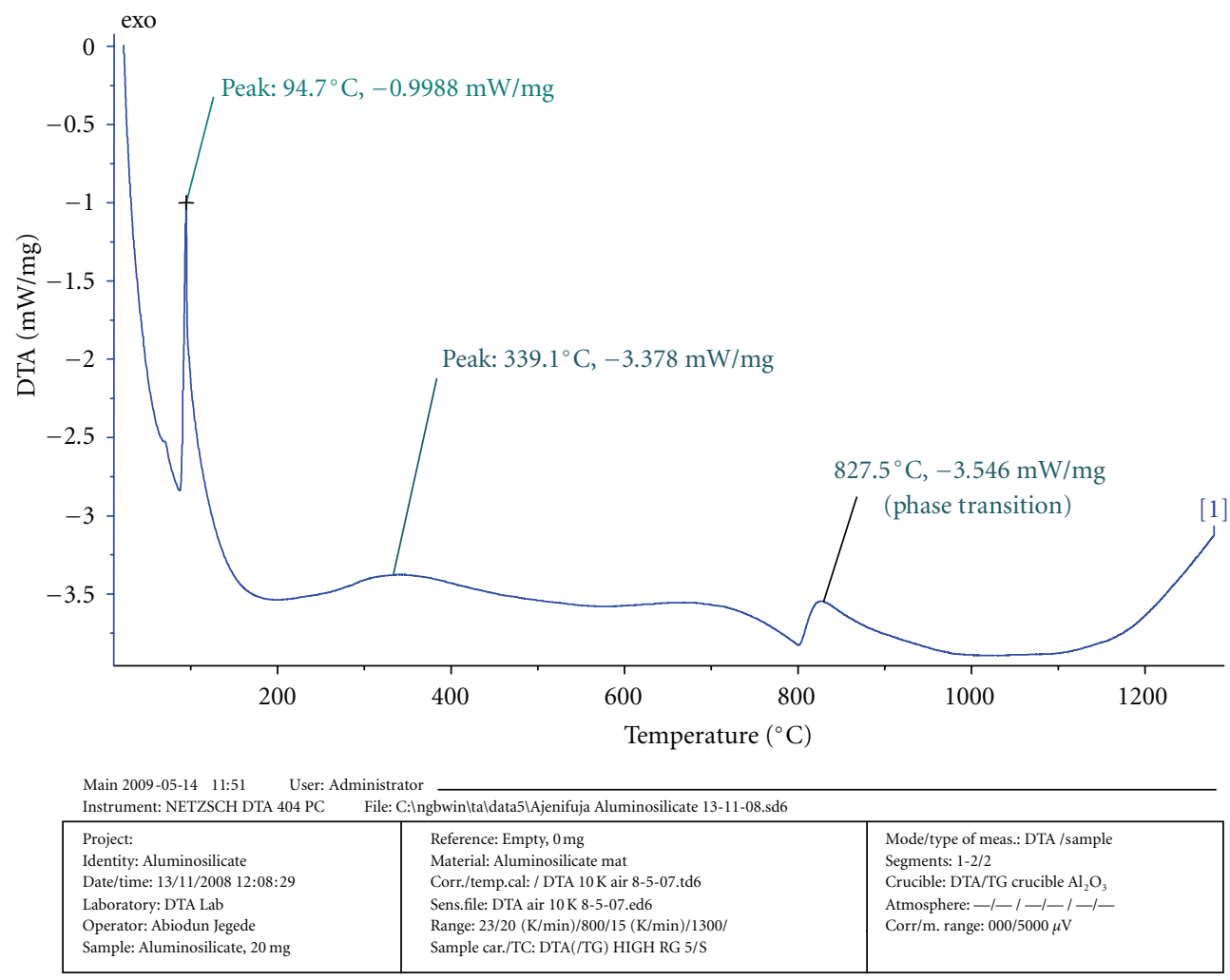

FIgURE 1: DTA thermogram of the aluminosilicate material.

of toxic elements leaching into the permeate stream is not likely, when the material is being used for filtration. There are no traces of toxic elements as mentioned earlier. In terms of oxide compositions for the aluminosilicate, the material resulted to be nearly silica $(76.05 \mathrm{wt} \%)$; with the next major oxide in the matrix being $\mathrm{Al}_{2} \mathrm{O}_{3}$ (15.33 wt \%), other oxides appeared as minor amounts. The composition of this material shows that it is very rich in silica and this material is abundantly available; the $\mathrm{SiO}_{2} / \mathrm{Al}_{2} \mathrm{O}_{3}$ ratio is 4.96, higher than that of the lateritic clay material. The utilization of this geological material will definitely reduce the stress of synthesizing silica from biomaterials such as food wastes and woods.

3.2. Thermal Properties of Aluminosilicate Mineral. Due to the open frame structure in some aluminosilicate minerals such as zeolites, faujasites, and others that belong to this group of mineral, water molecules are trapped in their framework. From the thermogram (Figure 1) of the differential thermal analysis carried out on the sample in the temperature range of $23^{\circ} \mathrm{C}$ to $1300^{\circ} \mathrm{C}$, three endothermic peaks at $94.7^{\circ} \mathrm{C}, 339.1^{\circ} \mathrm{C}$, and $827.5^{\circ} \mathrm{C}$ could be observed. The first peak at $94.7^{\circ} \mathrm{C}$ could be associated with the removal of atmospheric water content in the material while the second one at about $339.1^{\circ} \mathrm{C}$ could probably be attributed to the decomposition of some of the relict organic matter derived from plants and animals within the ceramic material, having become completely dehydrated, while the third peak is possibly the result of the phase transition in the material due to the effect of heat. An inference could be made due to the first reaction on the presence of water in the frame work of the material. 
TABLE 5: Total dissolved solid and $\mathrm{pH}$ results of filtered water.

\begin{tabular}{lccccc}
\hline \multirow{2}{*}{\begin{tabular}{l} 
Membrane filter \\
\cline { 2 - 4 }
\end{tabular}} & Water sample & \multicolumn{2}{c}{ Total dissolved solid (mg/L) } & \multicolumn{2}{c}{$\mathrm{pH}$} \\
After filtration & Before filtration & After filtration \\
\hline CMF1 & WS1 & 95.00 & 40.00 & 7.66 & 7.40 \\
CMF2A & WS2A & 95.00 & 81.00 & 7.66 & 7.51 \\
CMF2B & WS2B & 95.00 & 79.00 & 7.66 & 7.66 \\
CMF3 & WS3 & 95.00 & 52.00 & 7.66 & 7.30 \\
NIL & WS4 & 95.00 & 95.00 & 7.66 \\
\hline
\end{tabular}

TABLE 6: Plate count of bacterial load in water samples.

\begin{tabular}{lccccc}
\hline S/N & Ceramic membrane filter & Water sample & Before filtration & $\begin{array}{c}\text { Total count }(\mathrm{cfu} / \mathrm{mL}) \\
\text { After filtration }\end{array}$ & \begin{tabular}{c} 
Percentage reduction \\
\hline 1
\end{tabular} \\
\hline CMF1 & WS1 & 152 & 5 & $82.24 \%$ \\
2 & CMF2A & WS2A & 152 & NIL & $96.71 \%$ \\
3 & CMF2B & WS2B & 152 & NIL & $100 \%$ \\
4 & CMF3 & WS3 & & 152 & 152 \\
5 & NIL & WS4 & & & $100 \%$ \\
\hline
\end{tabular}

\subsection{Ceramic Membrane Physicochemical Performance Analysis}

3.3.1. Atomic Absorption Spectroscopy of Water Samples. The results of the atomic absorption spectroscopy (AAS) of the water samples before and after filtration are shown in Table 4. WS1, WS2A, WS2B, and WS3 are the water samples obtained after filtration treatment using ceramic membranes of different aluminosilicate-clay formulations; WS4 is the raw unfiltered water sample, tested as obtained from source. It was observed as seen in Table 4 that the concentrations of $\mathrm{Mg}$ and $\mathrm{Ca}$ ions have become lower after passing through the membrane filter, this is very important in the study because the two cations are important in the determination of water quality in term of hardness. It indicated that hardness of the filtered water samples WS1, WS2, and WS3 has been reduced with WS3 which was passed through the membrane filter CMF3 (made from pure zeolite material) having the lowest $\mathrm{Mg}$ and $\mathrm{Ca}$ ions concentrations. For other cations such as $\mathrm{K}^{+}$and $\mathrm{Na}^{+}$, the reverse is the case as cations concentrations became even higher, more than what was obtained in the raw water. This could be attributed to the selective ion exchange behaviour of zeolites with open frame structure, where the substitution of $\mathrm{Si}^{4+}$ by $\mathrm{Al}^{3+}$ results in having extra negative charge on the frame, thereby creating traps for positive ions: $\mathrm{H}^{+}, \mathrm{Na}^{+}, \mathrm{K}^{+}, \mathrm{Ca}^{2+}, \mathrm{Cu}^{2+}$, or $\mathrm{Mg}^{2+}$. An important property of aluminosilicate minerals are the ability to exchange ions, which relates to the charged surface of aluminosilicate minerals. Divalent $\mathrm{Mg}^{2+}$ and $\mathrm{Ca}^{2+}$ are assumed to be more attractive to the aluminosilicates than the small singly charged metal ions such as $\mathrm{K}^{+}$and $\mathrm{Na}^{+}$. For Manganese $(\mathrm{Mn})$ and Iron $(\mathrm{Fe})$, their ionic concentrations were reduced to nil in the treated water samples according to the result obtained.

The results of the $\mathrm{pH}$ and total dissolved solid (TDS) analyses in Table 5 showed that the $\mathrm{pH}$ of the water before and after filtration have a slight variation compared to the raw water (7.66). The sample with the lowest $\mathrm{pH}$ comparatively is WS3 that was filtered with pure aluminosilicate ceramic membrane filter (CMF3). Data shown on Table 5 indicated that the TDS in the filtered water samples WS1, WS2, and WS3 have greatly decreased. TDS is commonly measured with a conductivity meter which is correlative to specific salt solution. The measurement of water's electrical conductivity can provide an assessment of total ionic concentration. Filtered water samples WS1 and WS3 that passed through membrane filters CMF1 and CMF3 have total dissolved solid (TDS) of $40 \mathrm{mg} / \mathrm{L}$ and $52 \mathrm{mg} / \mathrm{L}$, respectively, which is an indication of a good functional behavior of the membrane filters.

\subsubsection{Antimicrobial Efficacy of the Microporous Ceramic Mem-} brane. Comparison of the water quality between raw water and filtered water carried out on the water samples is shown in Table 6. The experimental results showed that between $82.24 \%$ and $100 \%$ bacterial population can be removed by the ceramic membranes depending on the aluminosilicateclay formulation. The total bacterial concentration might comprise one or more of the pathogenic bacterium such as E. coli, Bacillus coagulans, Aeromonas veronii, Alcaligenes faecalis, and Pseudomonas. For membrane filters CMF1 and CMF2A, the results in Table 6 showed that there were $82.24 \%$ and $96.71 \%$ reduction in bacterial population, respectively. Table 7 shows the results of the bacterial biochemical test to ascertain the characteristics of bacterial species isolated from water samples using standard test procedures. At the end of the tests, the isolates were identified as Aeromonas veronii, Alcaligenes faecalis, Pseudomonas aeruginosa, Bacillus coagulans, Proteus mirabilis, Bacillus cereus, and Bacillus spp.

The approximate sizes of targeted microbes are given as follows: viruses $(0.005-0.3 \mu \mathrm{m})$, bacteria $(0.1-10 \mu \mathrm{m})$. Therefore, the ceramic membranes having pore size in the range $0.05 \mu \mathrm{m}$ to $0.1 \mu \mathrm{m}$ would hinder the movement of bacteria to the permeate stream, as shown from the result 


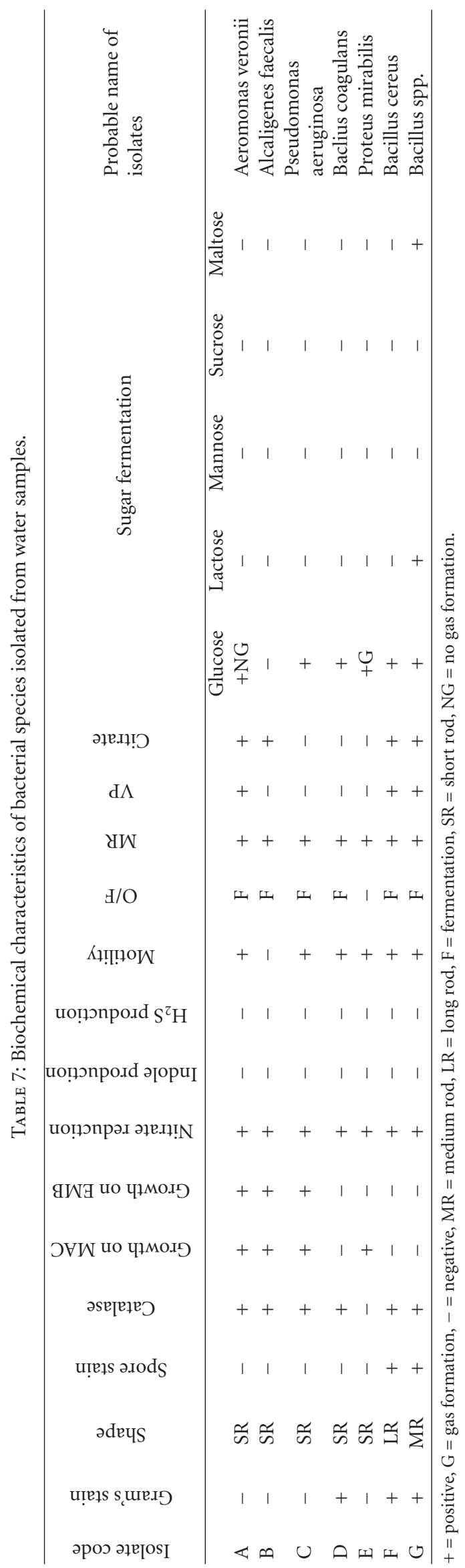


TABle 8: Output flux of the ceramic membranes.

\begin{tabular}{lccc}
\hline S/N & Ceramic membrane & Surface area $\left(\mathrm{m}^{2}\right)$ & Output flux and room temperature $\left(\mathrm{mL} / \mathrm{hr} \cdot \mathrm{m}^{2}\right)$ \\
\hline 1 & CMF1 & $2.27 * 10^{-4}$ & 8259.91 \\
2 & CMF2A & $1.77 * 10^{-4}$ & 31779.70 \\
3 & CMF2B & $1.77 * 10^{-4}$ & 33545.20 \\
4 & CMF3 & $2.55 * 10^{-4}$ & 11029.40 \\
\hline
\end{tabular}

in Table 6. Though, with right pore sizes, bacteria would not be allowed to pass through the membrane into the permeate stream through size exclusion and adsorption mechanisms, but there could be development of biofilm of microorganism over time and this can be inhibited by using appropriate production treatment method(s). Furthermore, the filtered water samples collected were visually observed and compared and were found to be much clearer than the unfiltered raw water.

3.3.3. Membrane Surface Morphology with Optical Microscope and SEM. The ceramic membrane pore size and surface morphology analyses were done using NIKON ECLIPSE ME600L optical microscope coupled with an image acquisition system and SEM (ZEISS Supra 40 with GEMINI column). Optical images obtained were magnified 100 times and the 3D surface morphology was studied using Image $\mathrm{J}$ image analysis program. The images acquired from the optical microscopes for CMF1, CMF2, and CMF3 were analyzed and presented as 3D surface plots in Figure 3 The size of each pore $(\approx 50 \mathrm{~nm})$ on the ceramic membrane surfaces shown in Figures 3(a), 3(b), and 3(c) using surface plot analysis ranged between $20 \mathrm{~nm}$ and $30 \mathrm{~nm}$. For the SEM analysis, one side of the four ceramic samples CMF1, CMF2A, CMF2B, and CMF3 were coated with gold in other to make samples conducting for procedure to be carried out as shown in Figure 2. From the SEM images obtained, it could be observed that the route of filtration was not only through the natural nanosized channels and pores, but also through the grain boundaries, especially for the pure zeolitic membrane, CMF3, and the matrices CMF2A and CMF2B, while the major routes of passage for the pure clay are the grain boundaries. Moreover, Figures 4(a), 4(b), 4(c), and 4(d) gave more illustrations on the morphological characteristics of the sintered ceramic membranes with different clay/aluminosilicate formulations. Figure 4(a) reveals the formation and distribution of some agglomerates of pure clay nano/microparticles with observed pores situated at the grain boundaries and larger pores interspersed within the structure at the agglomerates boundaries with mean diameter of about $50 \mathrm{~nm}$. Some of the pores now present in the pure clay ceramic could be attributed to the sites initially occupied by the wood microparticles, further contraction of clay particle due to the effect of heat at that sintering temperature must have additionally contributed to the reduction in size of the pores. Uniformly distributed pores are observed at the surface of the clay/aluminosilicate matrix membrane in Figures 4(b) and 4(c), the presence of cage-like regular pores which is characteristic of the

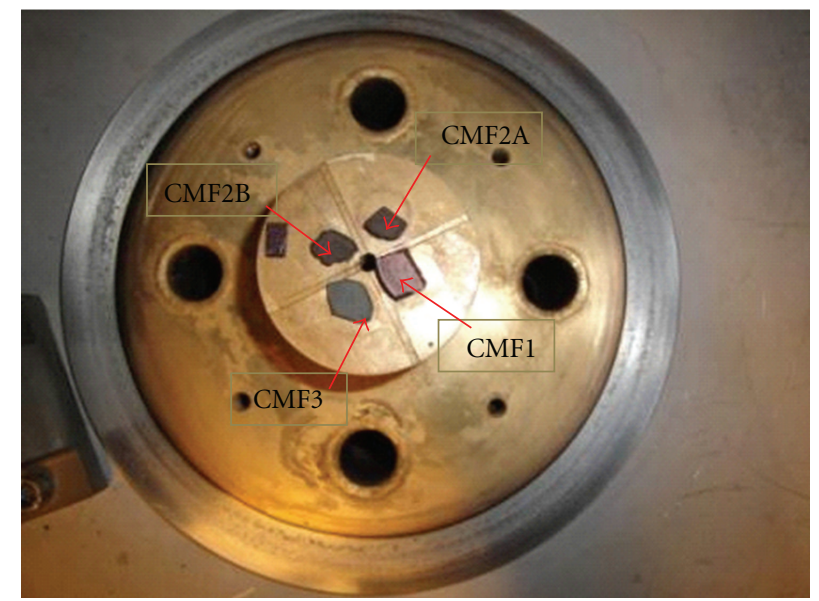

FIGURE 2: Coating of the ceramic samples on one side as pretreatmentfor SEM procedure.

aluminosilicate material and grain boundaries pores with clay particles can be said to enhance the porosity of the membrane. CMF3 was prepared solely with the synthesized zeolitic aluminosilicates powder; without the heat treatment the zeolitic aluminosilicate matrix was largely amorphous, this was shown on the XRD spectral obtained which gave no distinct information. The SEM image (Figure $4(\mathrm{~d})$ ) of the sintered zeolitic material membrane (CMF3) shows the regular pore arrangement, but randomly oriented phases and microstructures. The pores are more of uniform size between $50 \mathrm{~nm}$ and $100 \mathrm{~nm}$ on the material with irregular pores located at the grain boundaries.

3.3.4. Flux Output Characteristics. The flux output of the membrane filter element [10] is given as

$$
\mathbf{v}=\frac{\mathrm{V}}{\mathrm{St}},
$$

and the hydrostatic pressure due to the liquid alone as

$$
\mathbf{P}=\rho \mathbf{g h}
$$

where $\boldsymbol{\rho}$ is the liquid density, $\mathbf{g}$ is the gravitational acceleration, $\mathbf{h}$ corresponds to the height of the liquid relative to the membrane, $\mathbf{V}$ is the filtrate volume, $\mathbf{S}$ is the surface area of the membrane filter, and $\mathbf{t}$ is the time. Using the relations (1) and (2), the transmembrane pressure was found 


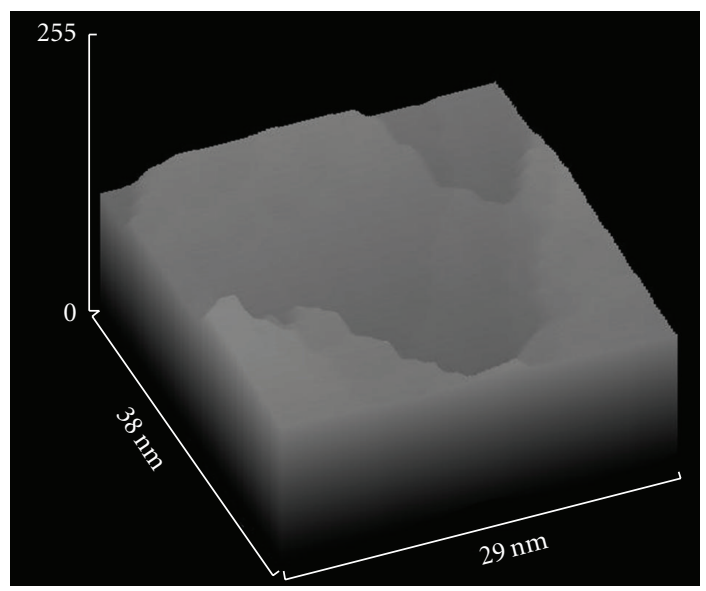

(a)

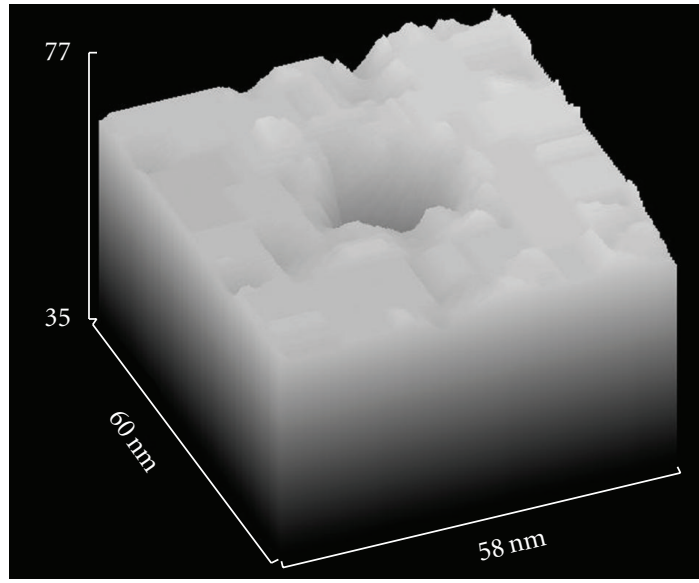

(b)

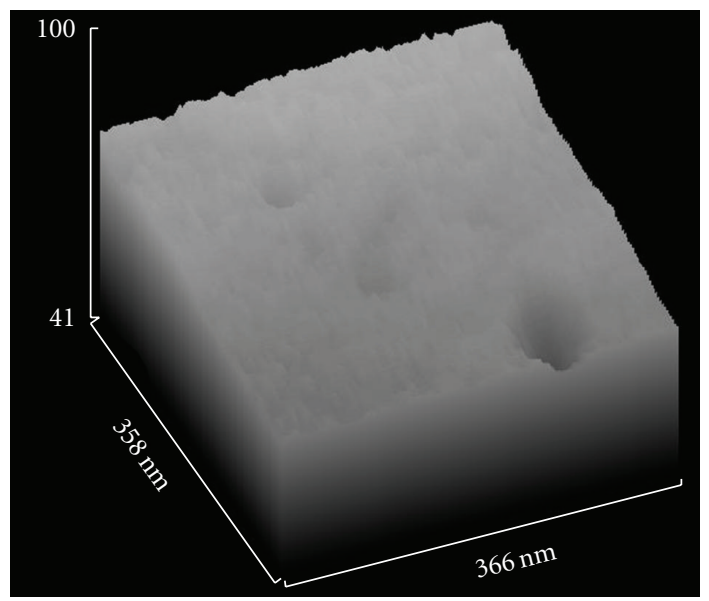

(c)

FIgURE 3: (a) Optical microscope single pore surface plot of ceramic membrane CMF1. (b) Optical Microscope single pore surface plot of ceramic membrane CMF2A. (c) Optical microscope single pore surface plot of ceramic membrane CMF3.

to be $0.0196 \mathrm{MPa}$ and the output flux at about $30^{\circ} \mathrm{C}$ found to be between $8259 \cdot 91 \mathrm{~mL} / \mathrm{hr} \cdot \mathrm{m}^{2}$ and $33545.20 \mathrm{~mL} / \mathrm{hr} \cdot \mathrm{m}^{2}$, respectively. Table 8 shows that clay/aluminosilicate ceramic combinations (CMF2A and CMF2B) have the highest flux output, which is an indication of better performance compared to CMF1 and CMF3 that were not mixed with either material.

\section{Conclusions}

With pore size down to the range between $0.05 \mu$ to $0.1 \mu \mathrm{m}$, the ceramic membranes were efficient at retaining bacteria and cysts through size exclusion mechanism and adsorption. Thus between $82 \%$ and $100 \%$ of bacterial population in water can be removed by the composite ceramic membrane filter; most rust and suspension particles can be removed almost entirely. The AAS result shows the ion exchange and adsorption capabilities of the ceramic membrane; this is not unconnected to the inherent properties of the raw materials used in the formulation of these membranes. It is also shown from the AAS result that, while the concentrations of $\mathrm{Mg}^{2+}$ and $\mathrm{Ca}^{2+}$ were reduced, the concentrations of $\mathrm{Na}^{+}$and $\mathrm{K}^{+}$ increased. The concentrations of the heavy metals (Fe, Mn) were reduced to nil; thus showing promising adsorption characteristics for the removal of heavy metals. Qualitatively, the zeolitic aluminosilicate and natural lateritic clay materials utilized in this work have similar properties in terms of elemental and chemical composition; however, there is a fundamental difference regarding the concentrations of the major oxides, which in turn has an effect on their physical appearance and mechanical strength. The combination of raw clay mineral and zeolitic aluminosilicate material improved the functional characteristics of the ceramic membrane filter in term of stability and flux output. Relatively easy technique of synthesizing microporous ceramic membrane without the use of expensive chemical sources, but using stable and readily available lateritic clay and aluminosilicate materials for water purification technology basically for small local and domestic use especially at the point of collection and storage has been presented. Further work is on going on the mechanical properties of the ceramic membranes. 


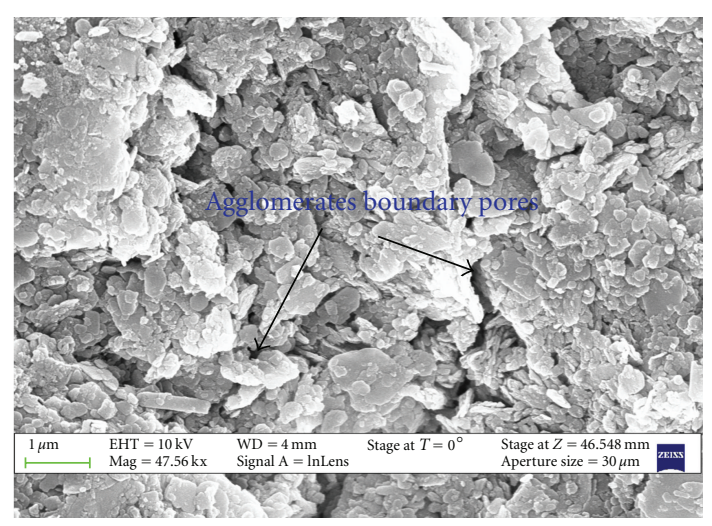

(a)

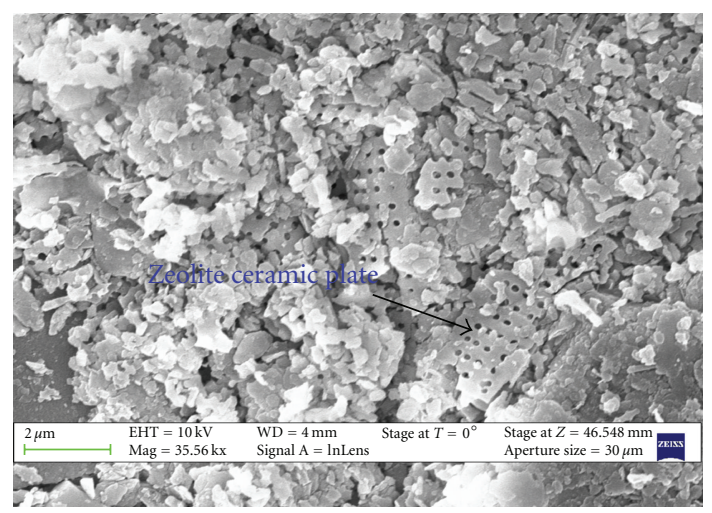

(c)

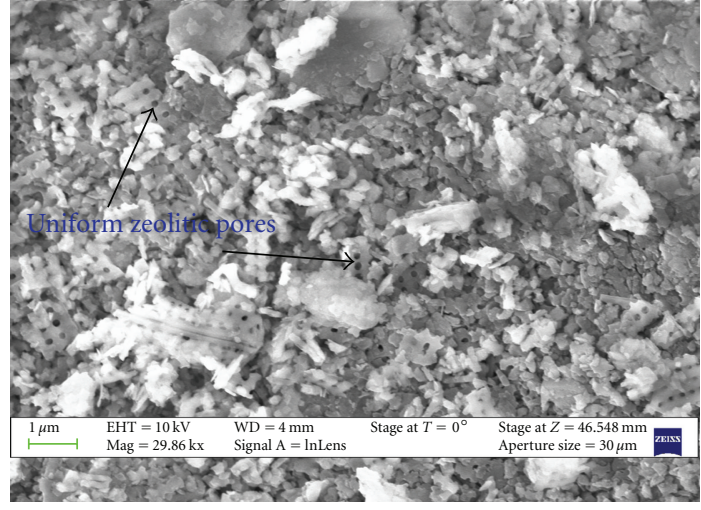

(b)

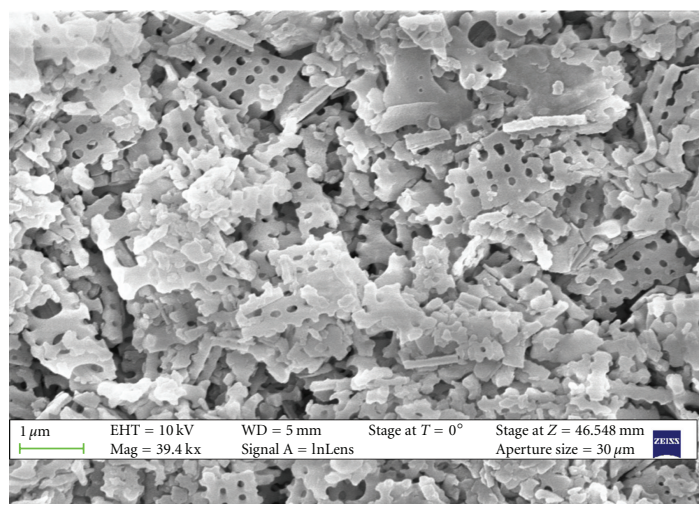

(d)

Figure 4: (a) Surface morphology of ceramic membrane CMF1. (b) Surface morphology of ceramic membrane CMF2A. (c) Surface morphology of ceramic membrane CMF2B. (d) Surface morphology of ceramic membrane CMF3.

\section{Acknowledgments}

The authors would like to thank Professor Siyan Malomo of Nigerian Geological Survey Agency, Professor M. B. Salami of Department of Geology, Obafemi Awolowo University, IleIfe, Nigeria, Dr. Taleatu Bidini of Department of Physics, Obafemi Awolowo University, Ile-Ife, Nigeria, and Mr. Biodun Adeoye of Engineering and Material Development Institute, Akure, Ondo State, Nigeria. The support of the Centre for Energy Research and Development, Obafemi Awolowo University, Ile-Ife, Nigeria is gratefully appreciated.

\section{References}

[1] L. V. Morozova, A. E. Lapshin, and I. A. Drozdova, "Preparation and investigation of porous aluminosilicate ceramic materials," Glass Physics and Chemistry, vol. 34, no. 4, pp. 443448, 2008.

[2] Y. Jia, W. Han, G. Xiong, and W. Yang, "Diatomite as high performance and environmental friendly catalysts for phenol hydroxylation with $\mathrm{H}_{2} \mathrm{O}_{2}$," Science and Technology of Advanced Materials, vol. 8, no. 1-2, pp. 106-109, 2007.

[3] X. Sui and X. Huang, "The characterization and water purification behavior of gradient ceramic membranes," Separation and Purification Technology, vol. 32, no. 1-3, pp. 73-79, 2003.
[4] A. E. Pagana, S. D. Sklari, E. S. Kikkinides, and V. T. Zaspalis, "Microporous ceramic membrane technology for the removal of arsenic and chromium ions from contaminated water," Microporous and Mesoporous Materials, vol. 110, no. 1, pp. 150-156, 2008.

[5] R. Del Colle, E. Longo, and S. R. Fontes, "Demulsification of water/sunflower oil emulsions by a tangential filtration process using chemically impregnated ceramic tubes," Journal of Membrane Science, vol. 289, no. 1-2, pp. 58-66, 2007.

[6] C. P. Gerba and J. E. Naranjo, "Applied and theoretical aspects of virus adsorption to surfaces," Wilderness and Environmental Medicine, vol. 11, pp. 12-16, 2000.

[7] J. Lukasik, T. M. Scott, D. Andryshak, and S. R. Farrah, "Influence of salts on virus adsorption to microporous filters," Applied and Environmental Microbiology, vol. 66, no. 7, pp. 2914-2920, 2000.

[8] S. Babel and T. A. Kurniawan, "Low-cost adsorbents for heavy metals uptake from contaminated water: a review," Journal of Hazardous Materials, vol. 97, no. 1-3, pp. 219-243, 2003.

[9] R. B. Wood and C. F. McAtamney, "Constructed wetlands for waste water treatment: the use of laterite in the bed medium in phosphorus and heavy metal removal," Hydrobiologia, vol. 340, no. 1-3, pp. 323-331, 1996.

[10] S. M. Azarov, T. A. Azarova, A. I. Rat'ko, N. V. Mil'vit, and S. V. Shemchenok, "Multilayer porous aluminosilicate ceramic," Glass and Ceramics, vol. 65, no. 3-4, pp. 88-91, 2008. 
[11] Y. Beppu, "Highly porous silicate ceramics prepared from saponite clay mineral," ATM, vol. 3, no. 1, pp. 35-38, 2001.

[12] Y. S. Han, J. B. Li, B. Chi, and Z. H. Wen, "The effect of sintering temperature on porous silica composite strength," Journal of Porous Materials, vol. 10, no. 1, pp. 41-45, 2003.

[13] S. J. Masten, S. H. R. Davies, M. Baumann, and B. Karnik, "Ceramic Membrane Water Filtration," US Patent, US 7578939 B2, 2009.

[14] J. Temuujin, T. S. Jadambaa, K. Okada, and K. J. D. MacKenzie, "Preparation of aluminosilicate precursor by mechanochemical method from gibbsite-fumed silica mixtures," Bulletin of Materials Science, vol. 21, no. 3, pp. 185-187, 1998.

[15] F. Yu, J. Yang, Y. Xue, J. Du, Y. Lu, and J. Gao, "Effects of talc and clay addition on pressureless sintering of porous $\mathrm{Si}_{3} \mathrm{~N}_{4}$ ceramics," Bulletin of Materials Science, vol. 32, no. 2, pp. 177$181,2009$.

[16] N. Eken-Saracoglu and N. Culfaz, "Clinoptilotile zeolite as a builder in nonphosphated detergents," Journal of Environmental Science and Health-Part A, vol. 34, pp. 1619-1626, 1999.

[17] S. U. Rege and R. T. Yang, "Limits for air separation by adsorption with LiX zeolite," Industrial and Engineering Chemistry Research, vol. 36, no. 12, pp. 5358-5365, 1997.

[18] F. S. Olise, O. K. Owoade, and H. B. Olaniyi, "An optimization of PIXE procedure for high-Z species in a lower Z matrix," Applied Radiation and Isotopes, vol. 68, no. 6, pp. 1030-1034, 2010. 

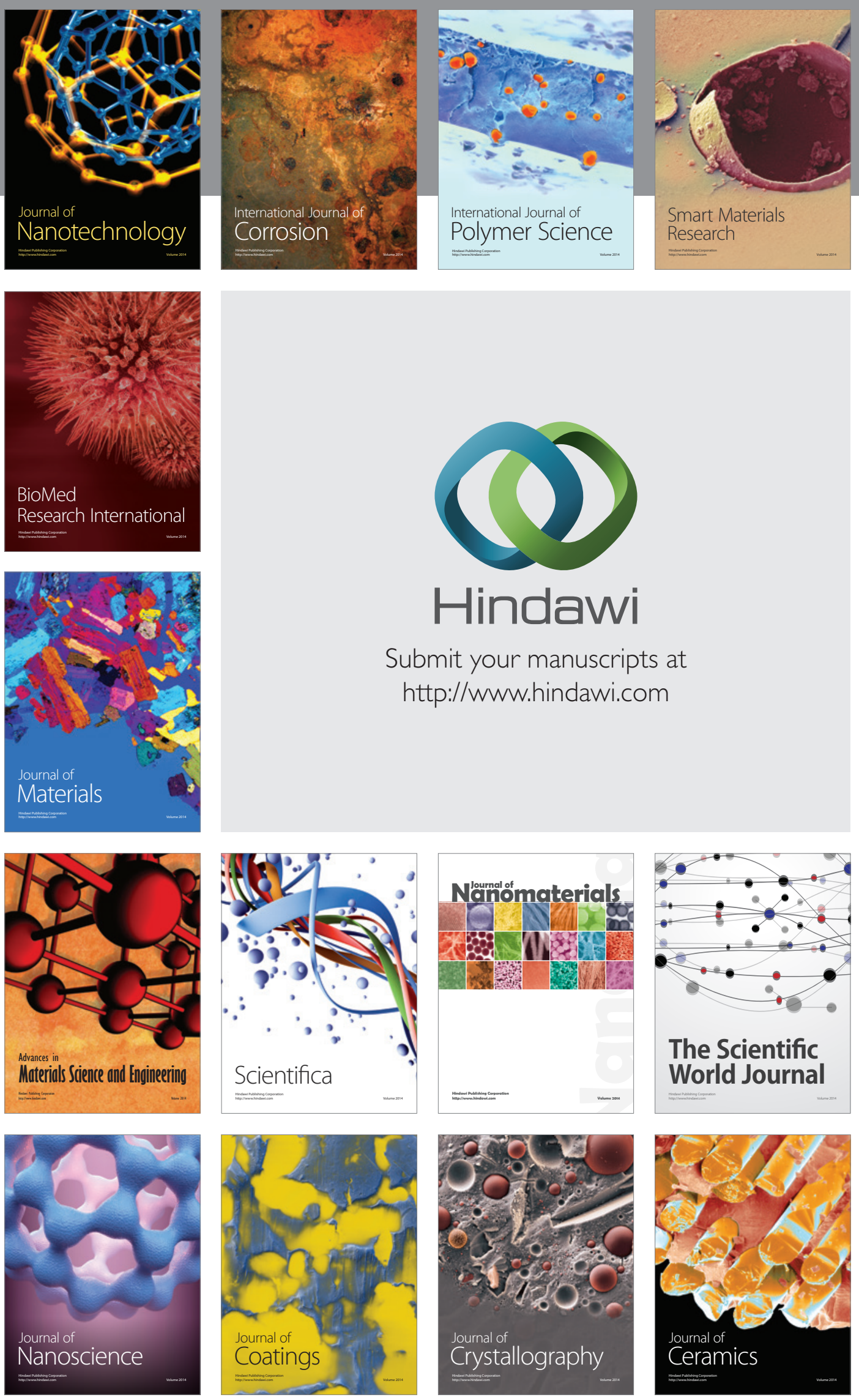

The Scientific World Journal

Submit your manuscripts at

http://www.hindawi.com

\section{World Journal}

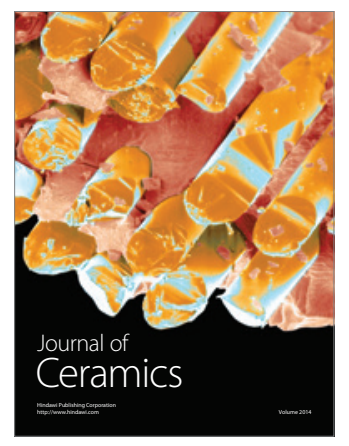

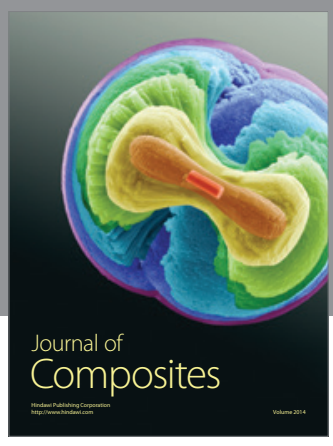
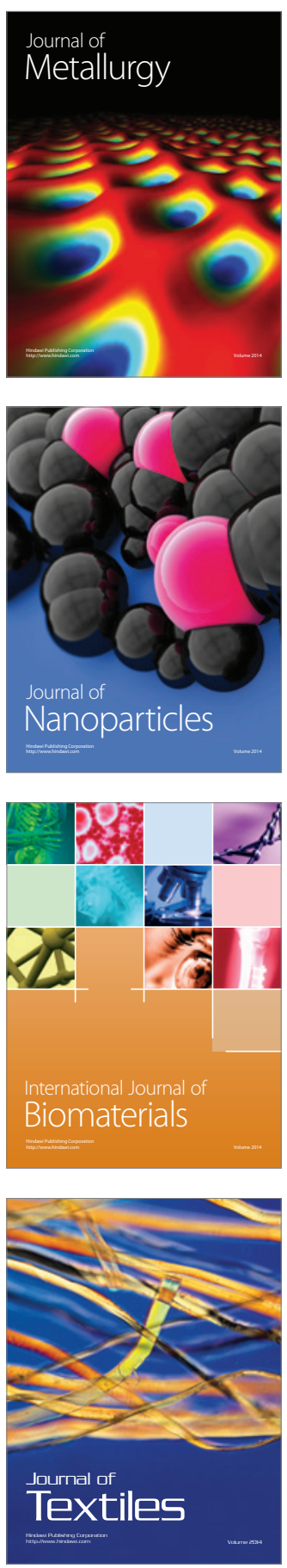